\title{
Effect of Learning Cycle Approach-based Science Teaching on Academic Achievement, Attitude, Motivation and Retention
}

\author{
Gökhan Uyanık \\ Faculty of Education, Kastamonu University, Turkey
}

Copyright $(2016$ by authors, all rights reserved. Authors agree that this article remains permanently open access under the terms of the Creative Commons Attribution License 4.0 International License

\begin{abstract}
The purpose of this study was to examine the effect of learning cycle approach-based teaching on academic achievement, attitude, motivation and retention at primary school $4^{\text {th }}$ grade science lesson. It was conducted pretest-posttest quasi-experimental design in this study. The study was conducted on a total of 65 students studying in two different classes in a state school in the province of Kastamonu, in 2015-2016 academic years fall term. Classes were assigned randomly as experimental group $(\mathrm{N}=33)$ and control group $(\mathrm{N}=32)$. Lessons were conducted based on learning cycle approach in experimental group. In control group, lessons were conducted based on teacher centered method. Data were collected through achievement test, attitude and motivation scales. For analyze the data, one-way ANOVA and independent t-test were used to compare the groups' scores. According to research results, it was found that a significant difference between experimental and control groups' academic achievement test and motivation scale post-tests scores, in favor of experimental group. Additionally, it was identified that the difference between retention test scores were also significant statistically in favor of experimental group. Yet, it was reached that the difference between attitude scale scores of experimental and control group were not significant statistically.
\end{abstract}

Keywords Attitude, Learning Cycle Approach, Motivation, Retention, Science

\section{Introduction}

In recent hundred years, importance given to education and instruction has gradually increased and still increases around the world. In this knowledge era, education and instruction become one of the most important activity. Raising individuals who have essential knowledge is a necessary for developing countries and bringing about innovations in all areas. It will be possible with giving effective and retentive education. In this sense, while being carried out education and training activities in schools, choosing methods and techniques coherent with lesson content will make easier being learned of lessons significantly. In recent years, constructivist approach that was started to implement in Turkey was come out as a theory which moved student to center. One of the student centered implementation based on constructivist approach philosophy is also learning cycle approach. Learning cycle approach offers a new approach to science educators. The learning cycle approach can be considered as a design implemented to science education which is used as the working methods of science and research method which is expressed as a scientific method [1]. With this aspect, learning cycle models encourage students to learning science by using scientific research processes. This approach requires to determine of target concept, collect information with observation, research and test with experimental methods by generating estimation and hypothesis [2].

Learning cycle approach is a learning approach that is based on mental development theory, brought forward by Piaget. This approach is based on the basis of discussion of the knowledge that students gained by means of conceptual development in class [3]. This approach carried out in three steps in classroom environment implementation and firstly developed by Karplus and his friends [4,5]. This approach is implemented in three stages. The learning cycle approach is a student-centered teaching approach which is composed of three main sections as exploration, term introduction and concept implementation. Exploration section consists of activities involving data collection and recording which is obtained from students' observations, measurements, experiments and travelling. The main purpose of this section is to encourage students to learning based upon their own experiences. The teacher is in a passive role in this section and gives instructions of experiment, activity or travelling which is carried out then observes and listens to students. 
The teacher asks questions to students to repeat their studies and leads them to think and comment. Objective is to establish a dialogue with their students' classmates, to make predictions and hypotheses from the activity that is done. Students examine new encountered tools and other materials in learning environment without helping of teachers and other people and they try to become experienced. In examining stage, while students can explain some things that encountered based on previous information, a number of problems and complex situations occur in their heads in some matters. Due to the fact that student cannot explain these questions with intelligence they have. Students need the information that teacher gives about answers of questions, so they have eagerness to learn and be ready to learn. This is described as being ready to receive knowledge.

In term introduction section, it is expected from students to explain and describe science concepts in the lights of data obtained from experiment, activity or travels with group discussions under the guidance of teacher. Science concepts are defined with their own words briefly. The teacher directs the definitions which was done by students, by asking questions and helps them to learn with the latest scientific definition and sentences made by students. The aim is to be defined the science concepts by students which are desired to teach. Knowledge which was obtained as a result of experiment, activity or travel must be connected to real life, so students can associate with their own lives by generalizing the data at this stage.

In concept implementation which is the third section, it is expected from students to study science concepts and use them. So, additional experiments, readings, films and discussions must be made. Defined concept knowledge can be extended more by using different sources. Thus, students try to establish relation between concepts and facts by seeing the meanings of concepts in other areas. This stage is quite beneficial for students who are especially under the average of mental development level, who cannot associate with their own gained experiences and teachers' telling, in a word, for students who have difficulty in achieving meaningful learning [6]. Learning cycle which is consists of three parts should be included into the content of science program and should be conducted at every stage of the educational process. By this way, students will obtain knowledge of evaluation and interpretation of scientific data [7]. Teacher takes not an active but a passive role in teaching process based on learning cycle approach. The role of teacher in learning cycle is to constitute a social and logical education environment cooperatively, based on finding out working paper that made think and supported by constructivist and other learning methods, exploring problems met in the daily life and generating meaningful solutions [8].

As an effective teaching method, attitude is also one of the factors that affecting student's learnings. Attitudes are learned trends towards content or other people, situations, institutions and certain objects [9]. [10] Indicate that attitude is a psychological trend and this trend is expressed e degree with positive or negative a particular asset by evaluating.
Attitudes associated with science and students', who were gained scientific attitudes, there will be an increase their attitudes towards science [11]. Studies conducted on attitudes were revealed that the attitudes acquired at early ages and they were not easily change unless there were very important experiences [12]. On most frequently mentioned affective learning products are the attitudes towards science area and science courses. Attitude plays an important role in the realization of learning due to the impact in formations of the decisions and behaviors of students. Studies revealed that students having a negative attitudes towards science classes and a decreasing tendency of the attitude scores the classes progresses. Whereas, creating a positive attitude towards science is one of the most important goals of science. It was stated that there were three important aspects in science teaching and one of which was the development of attitudes in order to ensure effective learning experience for students [13], because positive attitudes towards science of students to ensure more comfortable learning and ensure this learning will make more meaningful and retentive.

Such as attitude, one of the factors affecting the quality of learning is motivation. Motivation is also very important in terms of affect the success and learning, in the learning environment as in all areas of life. Because highly motivated students tend to show more effort and perseverance according to low motivated students in classroom activities and tasks [14]. Individuals' time spent to learn a subject, shows that the degree of their motivation [15]. It was determined that the factors affecting students' motivations in science education studies on the importance of motivations; the interests of students towards subjects, their notes which were taken in classroom, students' perceptions of task, success and failures of obtaining scientific knowledge, the general aim and orientations of students in science and understanding of scientific achievements [16].

Learning cycle approach can be effective in terms of providing meaningful learning of students in science lessons, arousing interest and supporting positive attitudes. It is important to be implemented and known of effective learning methods, technique and approaches by teachers, at primary school level that is learned of basic science concepts and be laid a foundation of learning life. The use of effective methods at teaching activities will provide meaningful and permanent learning in schools. Thus, it was determined that the impact of learning cycle approach in order to compare it with another teaching methods in some studies, this approach gave better results according to another methods $[17,18,19,20]$. The obtained results showed that teaching in terms of especially tangible concepts, the learning cycle approach was more effective than other methods [6]. When this approach used in science courses, it was determined that developed more concepts and mental abilities of students and students were satisfied the educational environment [6]. When they learn subjects in a meaningful and retentive way, they will be able to associate their knowledge with daily life and always will be more successful. It was seen in the literature that there was a few study about effect of learning 
cycle approach in the primary school level. Therefore, it was thought that this study, which was about evaluating the effectiveness of learning cycle approach at primary school-level, might be contribute to the literature. From this point of view, the purpose of research was to determine the effect of learning cycle approach-based science teaching on academic achievement, attitude, motivation and retention. For this purpose, it was sought an answer for the following sub-problems:

Is there any significant difference between;

1) Academic achievement test, attitude and motivation scales pre-tests scores of experimental and control group?

2) Academic achievement test, attitude and motivation scale post-tests scores of experimental and control group?

3) Retention test scores of experimental and control group?

\section{Materials and Methods}

\subsection{General Background of Research}

This study is a test model. Test models are research models which are produce to determine cause and effect relations under the control of researcher directly for data which is desire to observe [21]. Pretest-posttest quasi-experimental design was used in this research. Briefly, the main idea underlying all experimental researches is to state as "try something and observe systematically what's going on" [22]. Within the frame of this idea, it was examined that the effect of learning cycle approach-based science teaching on academic achievement, attitude, motivation and retention. Symbolic view regarding to experimental design of research is shown in Table 1.

Table 1. Symbolic view regarding to experimental design of research

\begin{tabular}{ccccc}
\hline Group & Pre-test & Process & Post-test & $\begin{array}{c}\text { Retention } \\
\text { Test }\end{array}$ \\
\hline \multirow{2}{*}{ Experimental } & $\mathrm{T} 1-\mathrm{S} 1-$ & $\mathrm{X}$ & $\mathrm{T} 1-\mathrm{S} 1-$ & $\mathrm{T} 1$ \\
\multirow{2}{*}{ Control } & $\mathrm{S} 2$ & & $\mathrm{~S} 2$ & \\
& $\mathrm{~T} 1-\mathrm{S} 1-$ & - & $\mathrm{T} 1-\mathrm{S} 1-$ & $\mathrm{T} 1$ \\
\hline
\end{tabular}

T1: Academic Achievement Test

S1: Attitude Scale

S2: Motivation Scale

X: Learning Cycle Approach-Based Teaching

While teacher centered direct teaching was conducted in control group, learning cycle approach-based science teaching was conducted in experimental group.

\subsection{Sample of Research}

The study was conducted on $654^{\text {th }}$ grade students studying in two different classes in a state primary school which was in Kastamonu city center, in 2015-2016 academic years fall term. Two different groups were assigned randomly as experimental group with 33 students and control group with 32 students.

\subsection{Data Collection Tools}

Achievement Test of "Recognize to Matter Unit", "Attitude Scale towards Science Course" and "Motivation Scale towards Science Learning" were used in this study developed by [23]. KR-20 reliability value of achievement test which consists of 28 multiple-choice questions was 0.78 , total distinctiveness was 0.48 and total difficulty value was calculated as 0.51 . Expert opinions considered to verify content validity. In each test, correct answer was determined as " 1 " point and at this state the highest point was determined as " 28 " point.

Attitude scale which was developed to determine attitudes of students towards science course consists of 18 items. In triple likert scale, answers of students were classified from negative to positive, "never", "sometimes" and "always". As a result of validity and reliability analysis, Kaiser-Meyer-Olkin (KMO) coefficient was identified as .73 and Bartlett Sphericity test significance level was identified as 0.00 . Total explained variance was calculated as $53.17 \%$ related to determined factors in four factor scale. Experts' opinions were considered for content validity. The scales' Cronbach Alpha $(\alpha)$ reliability coefficient was determined as .86. The most positive response was evaluated as " 3 " points on the scale and the most negative response was evaluated as " 1 " point on the scale. In this manner, it has been identified the highest score that could be obtained from the scale as " 54 " and it was defined as the lowest score that could be taken to scale as " 18 ".

The motivation scale which was developed to determine the motivation of students towards science learning consists of 19 items. In triple likert scale, answers of students were classified as "never", "sometimes" and "always". As a result of validity and reliability analysis, KMO coefficient was calculated as .75 and Bartlett Sphericity test significance level was 0.00 . According to core values of factors in scale, it was determined that there were 3 dimensions. Total explained variance related to determined factors was calculated as 51\%. The scales' Cronbach Alpha $(\alpha)$ reliability coefficient was determined as .87. Expert faculty members' opinions were considered for content validity. The most positive response was evaluated as " 3 " points on the scale and the most negative response was evaluated as "1" point on the scale. In this way it has been identified the highest score that could be obtained from the scale as " 57 " and it was defined as the lowest score that could be taken to scale as " 19 ".

In the view of this values, it was determined that developed attitudes and motivation scales could measure attitudes of primary school $4^{\text {th }}$ grade students towards science course and motivations towards science learning, in a consistent and reliable way, in explained factor structure. Before and after the experimental process; achievement test, attitude and motivation scales were implemented as pretests-posttests to experimental and control groups. Besides, after 8 weeks later from experimental implementation process, achievement test was implemented again as retention test to both two groups. 


\subsection{Implementation}

Experimental implementation was conducted on "Recognize to Matter Unit" in 7 weeks and 14 lessons. While learning cycle approach-based learning was conducted for experimental group, teacher centered learning was conducted for control group. Learning cycle method was designed in a guided questioning area by experiencing process of scientific research and questioning by supporting meaningful learning. Students were encouraged to participate actively in process of knowledge configuration in continuous social interaction by individually or collectively. Intriguing and interesting samples were used in all activities. Explaining their thoughts and thinking about these thoughts were supported in learning process. Students were encouraged to share their ideas with their partners and to configure common sense. It was provided opportunities to implement configured thoughts to new situations.

Students were studied in small groups (4-6 students) in order to increase the social interaction. More inclusive concepts were introduced earlier in experimental activities in topics. As experimental activities advanced, these inclusive concepts were handled in more detail and associated with different concepts. It was tried to connect with key concepts discussed in all experimental activities with each other and other concepts in science class "Recognize to Matter Unit". It was provided to experience scientific questioning-research process personally under the guidance of teacher.

Simple experiments based on learning cycle method consist of three steps. These were exploration, term introduction and concept implementation. Each activity was started by teacher with a demonstration experiment based on prediction-observation-explanation strategy. After demonstration experiment, students tried to explain observations by using their prior knowledge and concepts. It was used amazing activities in demonstration experiment and caught students' attention. Teacher avoided answering students' questions immediately after demonstration experiment. After demonstration experiment, students were given constructive feedback by considering preliminary concepts released in discussions about the topic. At this stage of learning cycle, students were aware of the problems while trying to explain their observations, so they set their objectives of activity which was held.

In section of term introduction, it was asked from students to define and explain in the light of data obtained from experimental activity that students made group discussion between each other and with the teacher's guidance. Students defined science concepts by their own words. By asking questions, teacher directed definitions which were done by students and ensured them to learn the latest scientific definition by using students' own sentences. At this stage, the aim was to describe science concepts which was planned to learn. As a result of experimental activities, it was tried to establish a contact with obtained knowledge and learned previously. It was asked from students to find relations in examined variables in discussions that all students participate in class. Instead of giving knowledge directly, teacher encouraged students to make inferences based on collected data and evaluate alleged explanations critically. All students were asked to explain their thoughts easily and think about both their own and other students' thoughts. Students discussed on suggested opinions until they reached a consensus.

Last section of learning cycle was considered as stage of applying concept which was configured newly. At this stage, students adapted configured concepts to new situations encountered in daily life. Students were directed to associate these new situations with concepts which were configured in previous activities. As experimental activities advances, it was tried to show relations with configured concepts. Moreover, it was provided to reach a common end by participating actively in process of information configuration and by exchanging opinions with discussions related to concepts and topics which were examined.

\subsection{Data Analysis}

Data was analyzed by using SPSS 21.0 Statistics Package Software. One-way ANOVA and independent t-test were conducted in order to compare scores of the experimental and control group. Data was tested on $\mathrm{p}<.01$ significance level.

\section{Results of Research}

\section{Results about First Sub-problem}

Before experimental implementation, achievement test of "Recognize to Matter Unit", "Attitude Scale towards Science Course" and "Motivation Scale towards Science Learning" were used as pre-tests to determine academic achievement levels, attitudes towards science course and motivations towards science learning of the experimental and control group. One-way ANOVA was used to compare obtained scores. Results about one-way ANOVA analysis can be seen in Table 2 . 
Table 2. ANOVA results regarding achievement test, attitude scale and motivation scale pre-tests scores of experimental and control group

\begin{tabular}{|c|c|c|c|c|c|c|}
\hline Pre-Test & Source of Variance & Sum of Squares & df & Mean Square & $\mathbf{F}$ & $\mathbf{p}$ \\
\hline \multirow{3}{*}{$\begin{array}{c}\text { Achievement } \\
\text { Test }\end{array}$} & Between groups & 7.742 & 1 & 7.742 & 2.833 & .097 \\
\hline & Within groups & 172.196 & 63 & 2.733 & & \\
\hline & Total & 179.938 & 64 & & & \\
\hline \multirow{3}{*}{ Attitude Scale } & Between groups & 5.123 & 1 & 5.123 & .232 & .632 \\
\hline & Within groups & 1390.938 & 63 & 22.078 & & \\
\hline & Total & 1396.062 & 64 & & & \\
\hline \multirow{3}{*}{ Motivation Scale } & Between groups & 14.686 & 1 & 14.686 & .271 & .605 \\
\hline & Within groups & 3431.561 & 63 & 54.469 & & \\
\hline & Total & 3446.246 & 64 & & & \\
\hline
\end{tabular}

$* \mathrm{p}<.01$

It can be seen in Table 2 that there is not any significant difference between the academic achievement test pre-test scores of experimental and control group $\mathrm{F}(1,63)=2.833, \mathrm{p}>.01$. According to this, it can be stated that before experimental process, groups were equivalent to each other in terms of academic achievement. Additionally, it can be seen in Table 2 that there is not any significant difference between the attitude scale pre-test scores of experimental and control group $\mathrm{F}(1,63)=.232$, $\mathrm{p}>.01$. According to this result, it can be stated that before experimental process, groups were equivalent to each other in terms of attitudes for science lesson. Also, it can be seen in Table 2 that there is not any significant difference between the motivation scale pre-test scores of experimental and control group $\mathrm{F}(1,63)=.271, \mathrm{p}>.01$. According to this, it can be stated that before experimental process, groups were equivalent to each other in terms of motivation levels for science learning.

\section{Findings about Second Sub-problem}

After experimental implementation, achievement test of "Recognize to Matter Unit", "Attitude Scale towards Science Course" and "Motivation Scale towards Science Learning" were used as post-tests to determine academic achievement levels, attitudes towards science course and motivations towards science learning of the experimental and control group. One-way ANOVA was used to compare obtained scores. Results about one-way ANOVA analysis can be seen in Table 3.

Table 3. ANOVA results regarding achievement test, attitude scale and motivation scale post-tests scores of experimental and control group

\begin{tabular}{|c|c|c|c|c|c|c|}
\hline Pre-Test & Source of Variance & Sum of Squares & df & Mean Square & $\mathbf{F}$ & $\mathbf{p}$ \\
\hline \multirow{3}{*}{$\begin{array}{l}\text { Achievement } \\
\text { Test }\end{array}$} & Between groups & 814.91 & 1 & 814.91 & 98.71 & $.000^{*}$ \\
\hline & Within groups & 520.105 & 63 & 8.256 & & \\
\hline & Total & 1335.015 & 64 & & & \\
\hline \multirow{3}{*}{ Attitude Scale } & Between groups & 150.399 & 1 & 150.399 & 2.208 & .142 \\
\hline & Within groups & 4291.355 & 63 & 68.117 & & \\
\hline & Total & 4441.754 & 64 & & & \\
\hline \multirow{3}{*}{ Motivation Scale } & Between groups & 3567.762 & 1 & 3567.762 & 119.021 & $.000^{*}$ \\
\hline & Within groups & 1888.484 & 63 & 29.976 & & \\
\hline & Total & 5456.246 & 64 & & & \\
\hline
\end{tabular}

$* \mathrm{p}<.01$

It can be seen in Table 3 that there is a significant difference between the academic achievement test post-test scores of experimental and control group in favor of experimental group $\mathrm{F}(1,63)=98.71,{ }^{*} \mathrm{p}<.01$. According to this, it can be stated that learning cycle approach-based science teaching was more efficient for improving academic achievement in comparison with teacher centered teaching. Besides, it can be seen in Table 3 that there is not any significant difference between the attitude scale post-test scores of experimental and control group $\mathrm{F}(1,63)=2.208$, $\mathrm{p}>.01$. According to this, it can be stated that groups were similar to each other in terms of attitude towards science lesson after experimental process. In addition to this, it can be seen in Table 3 that there is a significant difference between motivation scale post-test scores of experimental and control group in favor of experimental group $F(1,63)=$ $119.021, * p<.01$. According to this result, it can be stated that learning cycle approach-based teaching, which was implemented to experimental group, was more efficient for improving motivation for science learning.

\section{Findings about Third Sub-problem}

After 8-months the experimental implementation process, achievement test of "Recognize to Matter Unit" was 
implemented again to both groups as retention test. Independent t-test was used to compare scores obtained from retention test. Findings about independent t-test results can be seen in Table 4.

Table 4. Independent t-test results regarding retention test scores of experimental and control group

\begin{tabular}{ccccccc}
\hline Group & N & M & SD & df & t & p \\
\hline Experimental & 33 & 22.78 & .64 & & & \\
\hline Control & 32 & 11.59 & 1.91 & & 31.74 & $.000^{*}$ \\
${ }^{*} \mathrm{p}<.01$ & & & & & &
\end{tabular}

It can be seen in Table 4 that there is a significant difference between the retention test scores of experimental and control group in favor of experimental group $\left(\mathrm{t}_{(63)}=\right.$ $31.74, * p<.01)$. According to this result, it can be stated that learning cycle approach-based teaching, which was implemented to experimental group, provides more retentive learning. Line chart about the changes at academic achievement levels during the research process of experimental and control group, is seen in Figure 1.

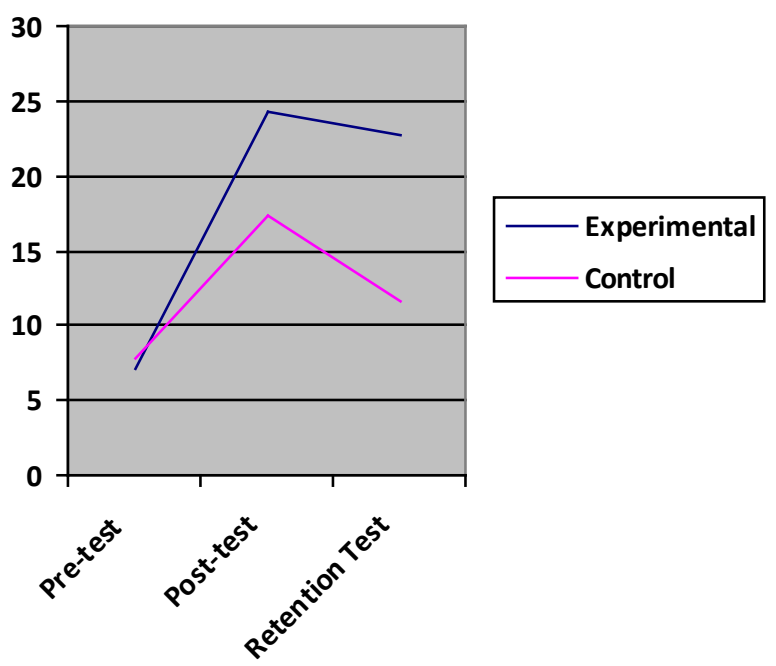

Figure 1. Changes at academic achievement levels during the research process of experimental and control group

According to Figure 1, before experimental implementation process, academic achievement levels of experimental and control groups were similar. After experimental implementation process, academic achievement levels of both groups have increased. But this increase was greater in the experimental group. Even more important to this, according to retention test results after 8-months the experimental implementation process, while there were not any significant decrease in experimental group's scores, there were a significant decrease in control group's scores. According to this, it can be stated that learning cycle approach-based teaching provided more retentive learning in comparison with teacher centered teaching.

\section{Discussion and Conclusions}

In this research, it was determined that the effect of learning cycle approach-based science teaching on academic achievement, attitude, motivation and retention. According to research results, learning cycle approach-based teaching was more effective than teacher centered teaching at increasing motivation towards science learning, academic achievement and retentive learning. This results are similar to the research results that learning cycle approach-based teaching activities to increase academic achievement $[17,20,24,25,26,27,28,29,30,31,32]$. These results showed that learning cycle approach was more effective than the other methods in teaching concrete materials and concepts, students' comprehension and understanding skills improved more in science lessons and students satisfied from educational environment.

Considering the obtained results, it can be stated that learning cycle approach-based science teaching increases academic achievement if it is given opportunities to students to participate actively in scientific examination-investigation process, to collect data, to make an inference, to configure concepts in social interaction and to think on either their or the others thoughts. This result was accordance with the research result of [32].

Such learning experiences provide that students can associate new knowledge with their preliminary knowledge by making easier knowledge configurations and can improve meaningful learning at primary school in Science lessons. Moreover, it was seen in this study that learning cycle approach-based teaching statistically increases motivations towards science learning of students. [1, 33, 34, 35] suggested in their studies that learning cycle approach-based teaching was effective for developing positive attitude towards science. Yet, it was stated that there was not any significant difference at attitude scale scores of experimental and control group students at the end of the study. This result supports the research results of [32, $36,37]$. Change of attitudes towards courses, events or situations sometimes can take longer times. Due to short implementation process ( 7 weeks) in this study, it might not be seen any significant difference statistically on experimental group students' attitude scale scores.

In addition to these results, it was determined that a statistically significant difference between the retention test scores of experimental and control group in favor of the experimental group. This result was similar to research result of [20]. Learning is permanent behavioral changes observed in individuals. Based on this definition, it can be said that in order to reach the aim of learning, it must be retention. In this sense, it is a requirement to retention of learning. The learning cycle approach-based teaching, which was used in this study, was provided realization of retentive learning.

According to the all of these results, it can be stated that learning cycle approach activities which enable students to participate actively in learning process to experience 
teaching process in social interaction, to comment on results by evaluating experimental data, to configure concepts and principles by their own might be more effective in science lessons, on the contrary of teacher centered teaching activities. In this context, it is offered to use learning cycle approach-based teaching at primary school in science lesson subjects. In next researches, effectiveness of learning cycle approach may be examined at primary level in different lessons and subjects.

\section{REFERENCES}

[1] Keleș, Y. (2010). Learning cycle models in science education. Journal of Mersin University Faculty of Education, 6(1), 41-51.

[2] Reiff, R., Harwood, W. S., \& Phillipson, T. (2002). The inquiry whell: A research-based model for doing scientific inquiry. Paper presented at the annual meeting of the National Assocation for Research in Science Teaching, New Orleans, LA. April 7-10.

[3] Lawson, A. E. (1995). Science teaching and the development of thinking. Belmont, CA: Wadsworth Publishing.

[4] Osborne, R., \& Wittrock, M. C. (1983). Learning science: A generative process. Science Education, 67(4), 489-508.

[5] Ayas, A. (1995).Development new programs and techniques of implementation: Evaluation of two contemporary approaches. Journal of Hacettepe University Faculty of Education, 11, 149-155.

[6] Özmen, H. (2004). Learning theories and technology supported constructivist learning in science education. The Turkish Online Journal of Educational Technology, 3(1), 100-111.

[7] Türkmen, H. (2006). How should science be taught by using learning cycle approach in elementary schools? Elementary Education Online, 5(2), 1-15.

[8] Davis, K. S., \& Falba, C. J. (2002). Integrating technology in elementary pre-service teacher education: Orchestrating scientific inquiry in meaningful ways. Journal of Science Teacher Education, 13(4), 303-329.

[9] Aiken, L. R. (1971). Psychological testing and assessment. (7th Edition). Pepperdine University, Boston.

[10] Eagly, A. H., \& Chaiken, S. (1993). The psychology of attitudes. Fort Worth Texas: Harcourt Brace Jovanovich College Publishers.

[11] Schibeci, R. A. (1983). Selecting appropriate attitudinal objectives for school science. Science Education, 67(5), 595-603.

[12] Kocabaş, A. (1997). Reliability and validity or the attitude scale towards music for stage two of basic education students. Journal of Hacettepe University Faculty of Education, 13, 141-145.

[13] Martin, R., Sexton, C., Wanger, K., \& Gerlovich, J. (1998). Science for all children. USA: Allyn and Bacon.
[14] Wolters, C. A., \& Rosenthal, H. (2000). The relation between students' motivational beliefs and their use of motivational regulation strategies. International Journal of Educational Research, 33, 801-820.

[15] Özçelik, D. A. (1992). Education programs and teaching. Ankara: OSYM Publishes.

[16] Tuan, C. S. (2005). The development of a questionnaire to measure students' motivation towards science learning. International Journal of Science Education, 27(6), 634-659.

[17] Abraham, M.R., \& Renner, J. W. (1986). The sequence of learning cycle activities in high school chemistry. Journal of Research in Science Teaching, 23(2), 121-143.

[18] Cate, J., \& Grzybowski, E. B. (1987). Teaching a biology concept using the learning cycle approach. The American Biology Teacher, 49(2), 90-92.

[19] Renner, J. W., Abraham, M. R. \& Birnie, H. H. (1988). The necessity of each phase of the learning cycle in teaching high school physics. Journal of Research in Science Teaching, 25(1), 39-58.

[20] Marek, E. A., Askey, D. M., \& Abraham, M. R. (2000). Student absences during learning cycle phase: A technological alternative for make-up work in laboratory based high school chemistry. International Journal of Science Education, 22(10), 1055-1068.

[21] Karasar, N. (2006). Scientific research method. Ankara: Nobel Publishes.

[22] Fraenkel, J. R., \& Wallen, N. E. (2006). How to design and evaluate research in education. (6. Ed.). New York: McGraw-Hill International Edition.

[23] Uyanık, G. (2014). Examining the effectiveness of conceptual change approach in fourth grade primary school science and technology course. (Unpublished doctoral dissertation). Gazi University Institute of Educational Sciences, Ankara.

[24] Fix, W.T., \& Renner, J.W. (1979). Chemistry and the experiment in the secondary schools. Journal of Chemical Education, 56(11), 737-740.

[25] Pavelich, M.J., \& Abraham, M.R. (1979). An inquiry format laboratory program for general chemistry. Journal of Chemical Education, 56(2), 100-103.

[26] Raghubir, K.P. (1979). The laboratory-investigative approach to science instruction. Journal of Research in Science Teaching, 16(1) 13-17.

[27] Allen, J.B., Barker, L.N. \& Ramsden, J.H. (1986). Guided inquiry laboratory. Journal of Chemical Education, 63(6), 533-534.

[28] Gunstone, R.F., \& Champagne, A.B. (1990). Promoting conceptual change in the laboratory. (ed. E. Hegarty-Hazel) The student laboratory and the science curriculum. Routledge: London.

[29] Smith, M. E., Hinckley, C. C., \& Volk, G. L. (1991). Cooperative learning in the undergraduate laboratory. Journal of Chemical Education, 68(5), 413-415.

[30] Lazarowitz, R., \& Tamir, P. (1994). Research on using laboratory instruction in science. (ed. D. Gabel) Handbook of research on science teaching and learning (pp. 94-128). New York: Macmillan. 
[31] Köseoğlu, F., \& Kavak, N. (2001). Constructivist approach in science teaching. Journal of Gazi University Faculty of Education, 21(1), 139-148.

[32] Köseoğlu, F., \& Tümay, H. (2010). Impact of learning cycle method on students' conceptual changes, attitudes and perceptions in basic chemistry laboratories. Journal of Ahi Evran University Faculty of Education, 11(1), 279-295.

[33] Musheno, B.V., \& Lawson A.E. (1999). Effects of learning cycle and traditional text on comprehension of science concepts by students at differing reasoning levels. Journal of Research in Science Teaching, 36(1), 23-37.

[34] Parker, V. (2000). Effects of a science intervention program on middle-grade student achievement and attitudes. School Science and Mathematics, 100(5), 236-243.

[35] Cavallo, A. M., \& Laubach, T. A. (2001). Students' science perceptions and enrollment decisions in differing learning cycle classrooms. Journal of Research in Science Teaching, 38(9), 1029-1062.

[36] Nuhoğlu, H., \& Yalçın, N. (2006). Effects of the learning cycle model of student achievement in physics laboratory studies. Journal of Turkish Science Education, 6, 49-65.

[37] Patli, H. U. (1998). Effect of the learning cycle method on achievement in high school chemistry instruction. (Unpublished MS Thesis). Marmara University Institute of Science, Istanbul. 